\title{
Movement through Time in the Southern Guianas: Deconstructing the Amerindian Kaleidoscope
}

\author{
Eithne B. Carlin and Jimmy Mans
}

The life of a person is the sum of his tracks. The total inscription of his movements, something that can be traced out along the ground. And the life course of a people, the totality of their ways, conventions, and conventionally encountered situations, is the sum of its 'tracks', the trails over its country along which experience is measured out. (Wagner 1986: 21)

\section{Introduction}

The immense linguistic diversity in Suriname had already existed for thousands of years before the European outthrust to the Americas. Different Amerindian groups had been present and moving around vast areas of Suriname and in and out of the neighbouring countries at a time when the borders of these presentday states did not exist as we know them today. ${ }^{1}$ After, or despite, colonisation by successive groups of Europeans, the fluidity of the frontiers remained for the Amerindians and led at any given moment in time to shifting constellations of population make-up within each of the three modern nation-states Guyana, Suriname, and French Guiana, and the contiguous areas of Venezuela and Brazil. In his influential 'Individual and Society' from 1984, Peter Rivière describes how Amerindian settlements in the Guianas seem to disintegrate and re-assemble in another location in like fashion, a process to which he cautiously ascribes the metaphor of a kaleidoscope. The key concept behind this Amerindian kaleidoscope appears to be the mechanism of residential mobility. Mobility here is defined as the sum of all movements (see Wagner 1986: 21; Ingold 2009: 36-37) and movement is regarded as any shifting from one location to another, as an interaction with the landscape, whether this be incidental, repetitive, or stable. It is generally in the case of the last-mentioned, whereby sustained and intense contact ensues, that a shift of ethnic identity

1 In keeping with the general practice of the English-speaking Caribbean and Guyana, the term 'Amerindian' is used here to refer to the indigenous populations. Where possible we use the ethnonym of the group.

(C) EITHNE B. CARLIN AND JIMMY MANS, 2015 | DOI 10.1163/9789004280120_005 
may occur. Identity, like mobility, is an interaction with the landscape, namely the social landscape. The aim of this chapter is, therefore, to show how shifting identities developed in tandem with, or as a result of, renegotiations of village formations and their repositioning in the landscape. To do this we deconstruct the histories and identities of two distinct but contemporaneously interacting Amerindian hubs of inter-ethnic activity, that is, ethnically complex and historically mobile groups: the Waiwai hub and the Trio hub. We show how residential mobility and repetitive contact between groups brought about processes of shifting ethnic identity.

In Section 2, we present an overview of the present-day Amerindian populations of the three nation-states and look briefly at the ethnic constitution of the groups in order to contextualise the setting in which the hubs developed. Identity in the Guianas in particular, and in Amazonia in general, necessitates using ethnic labels for discrete or overlapping ethnic groups. However, as we shall see in sections 3 and 4 , the labels used to identify specific groups are problematic, in part because an ethnic label does not necessarily entail ethnic affiliation, rather, many ethnic identificatory labels are historical constructs which tell us little about the 'real' or perceived ethnicity involved. We focus in these sections, in particular, on the histories of the Waiwai and Trio hubs respectively, both spanning Suriname, Brazil, and Guyana. These histories neatly exemplify converging and layered processes of ethnic heterogeneity hidden under a semblance of uniformity brought about by onomastic practice, cultural similarities, and performativity. We look here at the reasons for this ethnic mixing [historical], the mechanics of 'nested' identities [synchronic] (see Carlin 2011), and the different outcomes of linguistic and cultural mixing. We show their importance both for the people themselves as regards their ethnic allegiance and for our points of reference for them, that is, the nomenclature. In section 5 , we draw some conclusions as to what these insights can tell us about movements, localities, and the complexity of Amerindian identities.

\section{The Amerindian Languages of the Guianas}

Five different language families are represented in the Guianas, namely three of the larger linguistic families in South America, the Cariban, Arawakan, and Tupian families, and two isolates which constitute separate genetic units without any known relatives, namely Warao, and Taruma. The largest number of languages in Suriname and Guyana belongs to the Cariban family; in French Guiana there is an equal number of Cariban, Arawakan and Tupian languages, namely two of each. In Table 4.1, we show the distribution of the languages in 
each of the three nation states, Guyana, Suriname, and French Guiana. ${ }^{2}$ The geographical location of the Amerindian languages is shown in Fig. 4.1 on p. 82.

TABLE 4.1 Distribution of Amerindians in the Guianas

\begin{tabular}{|c|c|c|}
\hline Guyana & Suriname & French Guiana \\
\hline Cariban & Cariban & Cariban \\
\hline Kari'na (Carib) & Kari'na & Kari'na \\
\hline Akawaio (Kapon) ${ }^{3}$ & Wayana & Wayana \\
\hline Patamona (Kapon) & Trio & [Aparai] \\
\hline Arekuna (Pemon) ${ }^{4}$ & Akuriyo (ઐ $)^{5}$ & \\
\hline Makushi (Pemon) & Sikïiyana & \\
\hline \multirow[t]{2}{*}{ Waiwai } & Waiwai & \\
\hline & Tunayana-Katwena & \\
\hline Arawakan & Arawakan & Arawakan \\
\hline Lokono (Arawak) & Lokono & Lokono \\
\hline \multirow[t]{4}{*}{ Wapishana } & Mawayana & Palikur \\
\hline & & Tupian \\
\hline & & Teko (Emérillon) \\
\hline & & Wayãpí (Oyampi) \\
\hline \multicolumn{3}{|l|}{ Isolates } \\
\hline \multicolumn{3}{|l|}{ Warao } \\
\hline Taruma & & \\
\hline
\end{tabular}

2 In this table, an entry in round parentheses () indicates an alternative name found in the literature, and an entry between square brackets [] indicates the presence of a small number of an ethnic group that mainly lives elsewhere. For ease of reference, the names given in these tables are those used in the scientific literature and refer here to both the language and the group speaking the language. In the native languages themselves, there would be an addition of 'language', e.g., Lokono dian 'Lokono language', Kari'na auran 'Kari'na language' etc. There are two exceptions, namely Trio and Taruma which in their respective languages would be Tarëno ijomi 'Trio language' and Kwase dzïrzï 'Taruma language' (see below for more details).

3 Both the Akawaio and the Patamona in Guyana, and the Ingarikó in Brazil refer to themselves and their languages as Kapon and they are said to speak closely related languages. However, according to the Ethnologue (Lewis 2009), there are important differences in vocabulary between Akawaio and Patamona. For a discussion of the names, see ButtColson (2009a: 75-85). 
The numbers of speakers of each of the languages given in Table 4.1 is not necessarily commensurate with the number of people belonging to the ethnic groups and ranges dramatically from 2 Mawayana speakers of an ethnic group of over 100, to approximately 2700 (Trio) in all three countries (Mans 2012: 21). The Amerindian languages and the number of distinct Amerindian peoples in the Guianas have apparently since time immemorial been reduced by the formation of conglomerations, whether for reasons of intermarriage, war, sickness, or emigration, resulting in new identities and new ethnicities, language shift and language death. In the main, two patterns of language loss can be observed: (1) Languages losing out to a more dominant Amerindian language, for example Taruma shifting to Wapishana and Waiwai; Waiwai shifting to Trio, and (2) Languages that are dying out because their speakers are shifting to either a national language or a lingua franca, for example, Kari'na and Lokono speakers shifting to Sranantongo and/or Dutch.

In the following we look at the former pattern in order to demonstrate the process through which languages are lost and identities shifted. With the exception of Wapishana, which is losing out to English in Guyana and Portuguese in Brazil, the languages in our relevant area are only minimally, and in some cases not at all, affected by the national languages and/or lingua francas. Within the Guianas there are several main hubs of ethnic and linguistic complexity, for example, the Kapon and Pemon groups in the Circum-Roraima area straddling the Guyana/Venezuela/Brazil border, the Trio and the Waiwai hubs of Suriname/Guyana/Brazil. We know relatively little about the languages of the Kapon and Pemon groups except that each makes up a group of closely related dialects, many but not all of which are mutually intelligible to some degree. ${ }^{6}$ In part the confusion lies in historical processes that are no longer transparent: according to Migliazza (1980), for example, the people who now call themselves Makushi are in fact the result of a fusion, between 1900 and 1950, of remnants of various groups of the area, namely: Sapara, Wayumara,

4 Both the Makushi and Arekuna refer to themselves and their languages as Pemon although the two languages are not entirely mutually intelligible. Makushi is closely related to the Kapon languages. Other groups who also refer to themselves as Pemon are the Taurepan and Kamaragoto of Venezuela. For a discussion of the names, see Butt Colson (2009a: 110-113).

5 Although Akuriyo is seldom actively spoken nowadays, there are some rememberers of the language in two of the main Trio villages.

6 The major north and south Pemon dialects, Arekuna and Makushi, respectively, are mutually intelligible and only exhibit some minor dialectal variation. The degree of relatedness of the Pemon and Kapong languages, however, is still unclear (Audrey Butt Colson, pers. comm. 2012; see also Butt Colson 2009a, 2009b ). 
Maku, Paraviyana, Paushana, Jarecuna, Ingariko, Taurepan, and Wapishana, of which the last-mentioned group belongs to the Arawakan language family. Some of these groups still exist as separate entities speaking their own distinct languages. But as little as we know about these languages in the present, we are also not surprised by this kind of conglomeration. Such fusions of ethnically and linguistically distinct groups have been documented all over the Guianas since the seventeenth century, and took place most likely long before that as well.

In Suriname, there are three hubs, namely the Trio, Waiwai, and Wayana hubs, of which the first two, which straddle the border area of Suriname, Brazil, and Guyana, are the most striking in the light of their current convergences. ${ }^{7}$ As far as we know the linguistic consequences of these two main multi-ethnic hubs, Waiwai and Trio, are on the surface relatively straightforward; one dominant variety or language became the standard and the speakers of the original languages shifted, or are currently shifting, to the dominant varieties.

In the following section, we look more closely at the processes of residential mobility that have resulted in the heterogeneous nature of these two current conglomerations, deconstructing their kaleidoscopic configurations. We shall discuss not just the diversity of the groups making up conglomerations, but also what is hidden behind the autonyms and xenonyms that are used to designate these groups.

While the Waiwai and the Trio groups currently converge in the predominantly Trio village of Kwamalasamutu in Suriname, originally the result of missionary activity in southern Suriname starting in the late 1950s, they have quite distinct histories and origins. In this section, we trace the migratory history of the multi-ethnic Waiwai hub, showing the extent of language contact, residential mobility, and shared history of the subgroups.

The people we refer to as the Waiwai inhabit the Mapuera-TrombetasEssequibo-Sipaliwini area. They live in two villages in Guyana along the Cuyuwini, a tributary of the Essequibo, along the Mapuera River and its tributaries, the Anaua and Jatapuzinho, in Brazil, along the Sipaliwini River

7 The Wayana hub is found in the east of Suriname, French Guiana, and Brazil. This chapter deals only with the western hubs. 
in the Trio village Kwamalasamutu, and are represented by a few families along the Corantijn River, in Tigri/Casuela and in Sandlanding, closeby Apoera (see Fig. 4.1). ${ }^{8}$ According to Hawkins (1998: 25), there are approximately 1,800 Waiwai speakers in Guyana and Brazil. In Suriname there are approximately 250-30o Waiwai speakers.

The name Waiwai is a xenonym and according to folk etymology is a nickname used by the Wapishana-waiwai in Wapishana means 'tapioca' - to refer to the light skin colour of their southern neighbours. ${ }^{9}$ The people referred to as the Waiwai represent a conglomeration of originally different groups that spoke or still speak separate languages; these are given in Table 4.2, using the names they are known by in the literature. The language called Waiwai should therefore be seen more as a lingua franca than as a standardised language.

TABLE 4.2 Ethnolinguistic composition of the Waiwai

\begin{tabular}{|c|c|}
\hline Language/group name & Linguistic family \\
\hline Parukoto & $\begin{array}{l}\text { Cariban, probably basis of present-day Waiwai } \\
\text { language }\end{array}$ \\
\hline Shereo & Cariban, dialect of Hixkaryana \\
\hline Karafawyana $^{10}$ & $\begin{array}{l}\text { Cariban, Waiwai group, residential among the } \\
\text { 'Waiwai' since the early } 1980 \text { s }\end{array}$ \\
\hline Tunayana-Katwena & Cariban, Waiwai group \\
\hline Taruma (Kwase dzïrzi) & Isolate \\
\hline Mawayana & Arawakan \\
\hline
\end{tabular}

8 See Mans (2012). Extensive anthropological work has been carried out among the Waiwai in Brazil (Howard 2001; Dias 2005), and in Guyana (Fock 1963; Yde 1965; Mentore 2005; Alemán 2005). For linguistic work on the Waiwai in Guyana and Brazil, see Hawkins (1998) and for the Waiwai speakers of Kwamalasamutu, see Carlin (2006, 2011).

9 If this etymology is correct then we can place the Wapishana in Guyana earlier than generally assumed (1769, see Rivière 1963: 115, Carlin 2011: 227) since a Dutch mining director, Salomon H. Sanders, who was dispatched to accompany the Dutch trader Gerrit Jacobs to the interior, reports meeting some Weij Weij at the headwaters of the Essequibo in 1720/21 (see Bos 1998: 79ff).

10 Among the Waiwai speakers of Suriname, this group is referred to as Karafawsana and their language is deemed the most elegant variety of Waiwai. 


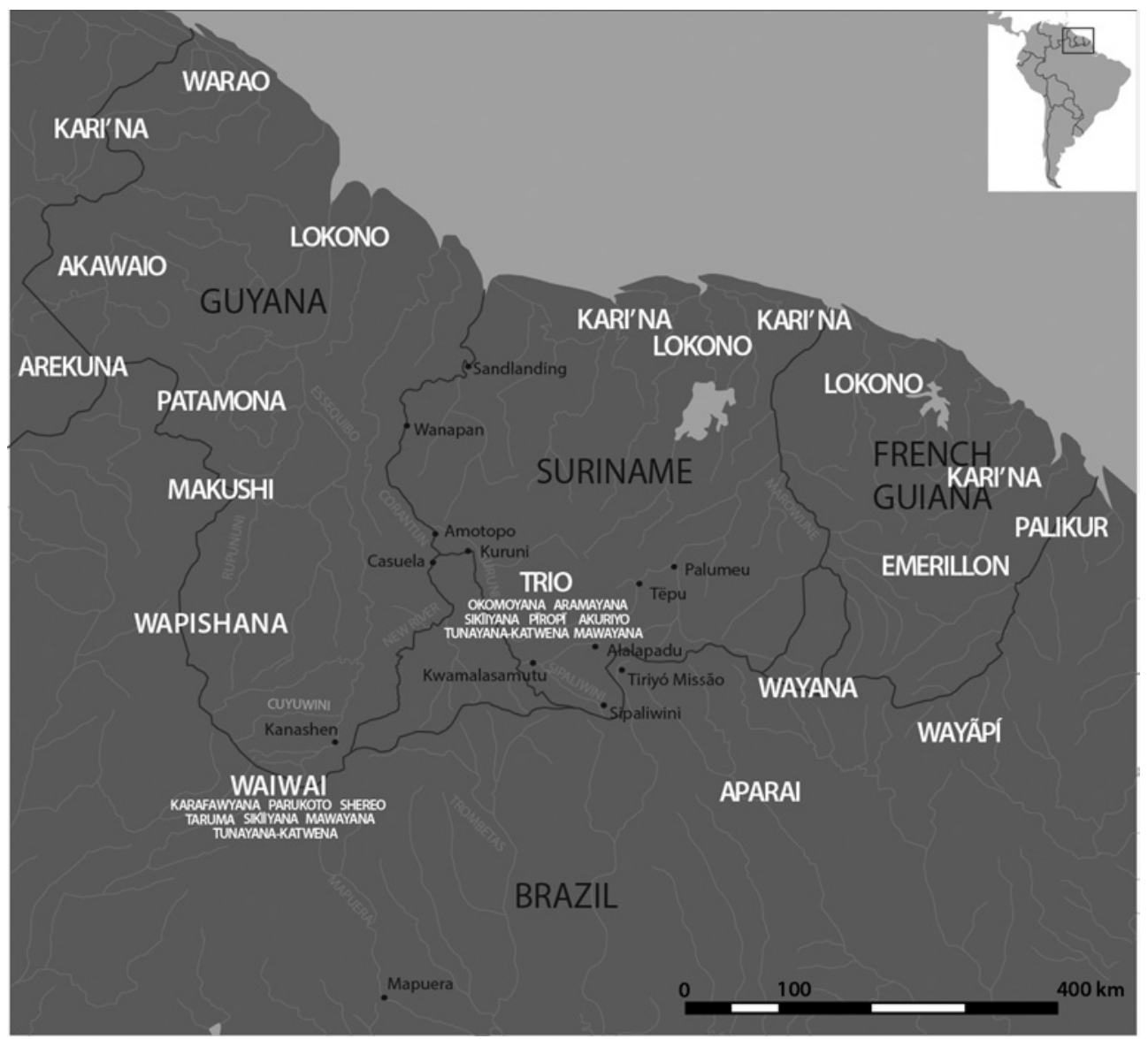

FIGURE 4.1 Distribution of the dominant languages in the Guianas emphasising the Waiwai and Trio hubs.

Our focus in the following is on two of the subgroups that came together to be known under the name Waiwai, namely the two groups that did not speak a Cariban language, and thus were farthest removed from the Cariban Waiwai core: the Taruma and the Mawayana.

As shown in Carlin (2011) the group we know as Taruma migrated northward from the Rio Negro to the Dutch territory of the Essequibo, at the latest around 1764 , where they were in contact with both the Wapishana, presently living on the Rupununi savanna in Guyana, and the Manaos, a once powerful Arawakan group that dispersed or became extinct in the 1770 . The name Taruma, nowadays assumed to be a xenonym, was already used as early as 1657, when they were mentioned in connection with a Portuguese slaving expedition at the mouth of the Rio Negro. Today we can positively identify them with 
the people who, on the Essequibo, were referred to by the ethnonyms Coarse (Schomburgk 1843), Ujessi (Farabee 1918), Kuase (Fr. Cary-Elwes, see (Butt Colson and Morton 1982: 215), and Uassahy (Gillin 1945). While the Wapishana assume that the name Taruma was given by them - taruma 'stinging ant'this can only be the case if the Wapishana and Taruma were in contact already at the mouth of the Rio Negro, for which we have no evidence. ${ }^{11}$

An alternative history of the Taruma put forth by Rivière (1966/1967) places the Taruma on the Essequibo much earlier, and suggests an Essequibo origin of this group. The other names given above are all derived from the Tarumas' autonym Kwase 'person' and the predicative form hujase 'I am a person'. Nowadays, there is one family living among the Wapishana who still claim Kwase (Taruma) ethnicity, and who still speak the language kwase dzïrzï.

The Taruma were traders who traversed the southern border area of Suriname/Brazil/ Guyana bartering their wares. They were renowned for their cassava graters, hunting dogs, and their high quality pottery which was much in demand among the more northerly Wapishana and Makushi. ${ }^{12}$ Though travelling traders, the Taruma did have at least two (semi)permanent villages in the south of Guyana, as far as four or five days apart, between the Cuyuwini river and the confluence of the Kamoa River with the Essequibo. This latter location is slightly to the east of the present-day Waiwai village Kanashen (see Fig. 4.1). To the west of these villages lived the Parukoto (< Waiwai). It is also in this area that one encounters the most hydronyms of Taruma origin, for example, Wakidiu (õã kichu) 'Sun River', Assimarikityou (assimari kichu) 'Anjoemara River', Kuasekidiu (kwase kichu) 'River of the People.' ${ }^{13}$

By 1843, the Taruma were living near the Cuyuwini very close to the Mawayana, an Arawakan group who apparently were living, at their own request, under the chief of the Taruma. Until Schomburgk's expedition in the late 1830 s the sources are silent on the Mawayana 'Frog People. ${ }^{14}$ We know that they hailed from the Mapuera-Trombetas region of Brazil, the homeland of the Parukoto group, and that they traversed the area up as far as the Essequibo where from the 1830 onward their previous repetitive and later sustained

\footnotetext{
11 There is a tributary of the Rio Negro just north of Manaos called the Tarumã.

12 On the basis of their pottery, archaeologists Meggers and Evans postulated a Taruma Phase (see Meggers and Evans 1960; see also Boomert 1981; Plew 2005; and Rivière 1966/67).

13 The hydronyms given here are just a few of those found in Schomburgk (1845) and Butt Colson and Morton (1982), and as they are currently shown on maps. The original Taruma rendering is given in italics based on Carlin's short fieldwork among the Taruma in 2005.

14 There is a mention of a group called Mapoyena in the Trombetas region by Fray Francisco de San Marcos in 1725, but we have no definitive evidence that these were the Mawayana (see Rivière 1963).
} 
contact with the Taruma resulted in both groups joining the Waiwai. References to the Mawayana are found in Schomburgk (1845) as Maopityan and in Farabee (1918) as Mapidian: Mawayana is apparently the Arawakan name, the two versions given above are the calqued Wapishana name for the Mawayana, $m a o=$ mawa 'frog' and pidan (pichan) 'person' corresponding to -yana 'ethnic group'. They were called Mawakwa by the Taruma, mawa + kwa(se) 'frog' and 'person'. However, according to their own reports the name Mawayana is also an umbrella term subsuming at least three different groups, the Wadayana, Jiwiyana, and Buuyana, names which are not mentioned anywhere in the literature. The remaining Mawayana cannot recount the sequence of events that led to their being subsumed under the name Mawayana.

Some thirty years later in the 1870 s, the Mawayana and Taruma were both trading together with the Wapishana and the Waiwai (Barrington Brown 1877: $247-51$ ). In contrast to what would come about in the following century, these two co-residential and cooperating groups did not merge under one ethnonym, in spite of the dominance of the Taruma and the fact that Taruma men were marrying Mawayana women (Rivière 2006: 153), rather they co-existed as separate entities with separate identities speaking two unrelated languages. ${ }^{15}$ Co-residentiality is therefore not a priori a reason to relinquish one's own ethnic or linguistic identity, the reasons seem to be more of a politico-economic nature where trade capability and mobility reinforce separate identity, whereas a weakened constitution undermines the economic clout required for selfassertion. We can assume a certain degree of passive knowledge of each other's languages, or it is possible that a common language was used in their interactions. ${ }^{16}$ The most likely candidate is a form of Waiwai since the subgroups

15 The phonologies of Taruma, Mawayana, and Wapishana are similar in that they all have phonemic implosive consonants; Mawayana and Taruma share nasalisation processes; Mawayana and Wapishana share cognates for roughly half of their basic vocabulary. All three languages share with the Cariban languages cognates for their flora and fauna, probably indicative of an older layer of Arawakan or Tupian diffusion of these terms. The three languages also exhibit common loanwords for trade items. It is not possible to say what, if any, influence Mawayana and Taruma had on each other in the period they were together. We do know, however, that Mawayana borrowed some functional categories, including a first person plural exclusive pronoun, from Waiwai (see Carlin 2006).

16 The former situation finds its parallel in Palumeu in Suriname, half of whose inhabitants speak Trio and the other half Wayana. A certain degree of passive bilingualism exists, but active bilingualism is rare and only seems to occur among the children of mixed Trio/ Wayana descent, though it is not generally practiced as these bilinguals tend to stick to one or other of the languages. Likewise, a Mawayana couple that Carlin worked with in Kwamalamasutu steadfastly spoke different languages to each other, the wife spoke 
Parukoto and Tunayana upheld intense trade relations with them. Moreover, the Tunayana, and their sister group the Katwena captured Mawayana women as their wives with some degree of regularity so we can assume some degree of passive bilingualism emerging from these unions.

From the early 1920s, the numbers of the Taruma and Mawayana had dwindled so much that the Mawayana and most of the Taruma became absorbed into the Waiwai group (see Butt Colson and Morton 1982), and some Taruma joined the much larger Wapishana group further north. ${ }^{17}$ It is interesting to note that at the time of missionary Fr. Cary-Elwes' visits to the 'Waiwai' in 1919, 1922, and 1923, almost all the rivers he names in his diary are Taruma names given by his Taruma assistant who also spoke Wapishana. In the course of his communication with the Waiwai in the village Kabaikidiu, his assistant interpreted from Wapishana into Taruma upon which a few villagers translated into Waiwai. ${ }^{18}$ We can conclude from this that the languages were still spoken at that time and that the shift to Waiwai had not taken place. The entire area between the rivers Mapuera in the south, Cuyuwini in the north, Rupununi in the west, and Corantijn in the east was the locus of repetitive and in some cases intense sustained interaction between all these different groups, the Cariban Parukoto, Tunayana, Shereo, Pianakoto, the Arawakan Mawayana, and the linguistically unclassified Taruma, and nameless others. ${ }^{19}$

A process of assimilation and linguistic absorption that consciously began in the 1920s, partly due to Fr. Cary-Elwes' urging the Taruma to intermarry with the Waiwai or else face extinction, was claimed to have reached its completion by the 1960 s with the waiwai-isation of the Taruma and Mawayana. In their dealings with other Amerindian groups and with non-Amerindians they assumed 'Waiwai' identity and thus on the outside ceased to exist as separate identities with their own territory. Thus, a salient factor in sustaining group identity would appear to be locality, that is, identity is intricately bound up with one's own space in the landscape. In good Amerindian spirit, however, these identities had only fallen dormant, not dead.

Mawayana and the husband Waiwai, and each had a passive knowledge of the other's language.

17 The Wapishana were also in the process of absorbing another smaller group who spoke an Arawakan language, namely the Atorai, of which, likewise, some few speakers still remain in Guyana.

18 See Butt Colson and Morton (1982: 229-230). The authors also note that unwittingly CaryElwes was actually in a Brazilian Waiwai village.

19 As stated above, trading also took place regularly with the Wapishana and the Makushi further north. 
In the late 1950s an American missionary who had been working with the Waiwai in Brazil and Guyana recruited some 'Waiwai' to undertake with him the evangelisation of the Trio groups of southern Suriname. This group was made up of ethnic Tunayana, Katwena, and Mawayana. These three groups had been in contact with each other for nearly a century, now raiding each other for wives, now trading with each other. One of this small group was a Mawayana who was the product of a hostile meeting of the Trio with the Mawayana. The Trio had come to the Mawayana to trade but a few of their party were killed and their wives were taken by the Mawayana (Dowdy 1963: 231). So it was that this one Mawayana spoke some Trio before he arrived in Suriname. The missionary Leavitt, assisted by this small Waiwai group, founded the village Alalapadu where many Trio groups gathered before moving to Kwamalasamutu in the mid 1970 (see Section 4 below).

In Suriname this group of people, all of whom spoke Waiwai as a common language to each other, was, and still is, collectively referred to as Waiwai by the Trio with whom they now live in the village of Kwamalasamutu. The Waiwaispeaking group has grown both in numbers and importance over the last fifty years, and Waiwai has become an important language in this village. Over the years, the Waiwai-speaking group was augmented by a small group of Sikiiyana from Brazil. While to the outside world the inhabitants of Kwamalasamutu are referred to as Trio (see the following section for the formation of the Trio), as regards the structure and layout of Kwamalasamutu we can distinguish ethnic areas inhabited by the following groups: Trio, Akuriyo, Tunayana (Katwena), Mawayana, and Sikïiyana. ${ }^{20}$

The Kwamalasamutu setting presents us with the perfect case to examine in situ the linguistic and identity patterns that are emerging, or being reinforced. The identity that is projected to and by the Surinamese government is somewhat ambiguous: on the one hand, all the people of Kwamalasamutu are referred to as Trio, yet on the other hand, the government recognises some of the different ethnic groups in the form of leadership roles, that is, several leaders (Captains) have been appointed, namely one each for the following

The Katwena often refer to themselves as Tunayana-Katwena. It is not entirely clear what the distinction between the two is now as they both seem to have spoken the same language. However, we know from the Mawayana that a distinction was made before in that the Tunayana (in Mawayana: Unnïyana) captured Jiwiyana women whereas the Katwena took Wadayana women, both subgroups of the Mawayana. We know that Katwena is also an umbrella term since the Munuhpëyana 'Rat People' also claim Katwena identity. Farabee (1924) gives the Katwena (Katawians) as a subgroup of the Parukoto, but claims that a Tunayana (Toneyana) he met stated that his language was nothing like Parukoto. On this note Farabee, unfortunately not a reliable source for linguistic information, also mentions that the Sikiïyana (Chikena) language appears to be very close to Parukoto. 
groups: Trio (one Paramount Chief and one Head Captain); Okomoyana (see below); Mawayana; and Tunayana (Katwena). The groups without a designated Captain are thus the Akuriyo and Sikiiyana, and several of the Trio subgroups. Indeed in the village a clear distinction is made between the different ethnicities, and not all have equal status, and not all are a desirable marriage partner. All inhabitants speak Trio, albeit with different degrees of competence. Many of the oldest generations of the non-Trio learned Trio as a third or fourth language; they remained speaking their original languages in the home. Outside the home the Waiwai-speaking groups of the generations 40-65 years old speak Waiwai with each other and Trio with all others; the generations below 40 often have at least a passive knowledge of Waiwai but more readily speak Trio to all villagers. The youngest generations are raised with Trio. Some few Trio have a passive knowledge of Waiwai but do not speak it themselves. In general the generations of the Waiwai-speaking groups and the Akuriyo above 40 years old, though fluent speakers, do not have the stylistic range and grammatical competence of a native Trio speaker. To illustrate, we give in Table 4.3 a summary of the language practices of the Mawayana (updated from Carlin 2006: 317).

\begin{tabular}{ll}
\hline Generation of ethnic Mawayana & Languages spoken with whom \\
\hline oldest $( \pm 75$ years $)$ & Mawayana among each other $(2$ sisters $) ;{ }^{21}$ \\
& Waiwai with their own children and with \\
& other Waiwai groups; \\
& Trio with their grandchildren, great- \\
& grandchildren, and all other villagers \\
& Waiwai with their parents and their own \\
& children, and with other Waiwai groups; \\
& Waiwai and increasingly Trio with their \\
second generation $( \pm 60$ years $)$ & grandchildren; \\
& Trio with all other villagers
\end{tabular}

21 Since 2006 when this table was first published, two fluent speakers of Mawayana and one man with a good passive knowledge of the language have passed away. There may be as many as $130-150$ self-ascribed Mawayana in Kwamalasamutu. The information in this table is based on Carlin's own observations and on interviews with the Mawayana in the period 2002-2011. 
TABLE 4.3 (cont.)

\begin{tabular}{|c|c|}
\hline Generation of ethnic Mawayana & Languages spoken with whom \\
\hline third generation ( \pm 40 years) & $\begin{array}{l}\text { Waiwai with Waiwai speakers of older and } \\
\text { peer groups; } \\
\text { decreasingly Waiwai and increasingly Trio } \\
\text { with their own children; } \\
\text { Trio with all other villagers }\end{array}$ \\
\hline fourth generation ( \pm 22 years) & $\begin{array}{l}\text { Trio with everyone although some may have } \\
\text { a passive knowledge of Waiwai }\end{array}$ \\
\hline fifth generation (<20 years) & Trio only \\
\hline
\end{tabular}

The Tunayana-Katwena differ in one crucial aspect from the Mawayana practices as sketched here, namely some members of the third generation have started a linguistic and cultural awareness group ${ }^{22}$ and do speak their own language more to their children. Although given that the peers of these children otherwise speak the lingua franca form of Waiwai, this is not having much impact, and Trio remains the first and primary language of the younger generations. Thus while present-day Trio was a third or fourth language for all these Waiwai-speaking groups in Kwamalasamutu, its own history was in a sense similar to that of Waiwai in that it became a lingua franca for several smaller related groups in the first half of the twentieth century. Prior to the arrival of that small Waiwai-speaking group in Suriname in the 196os, a merging of different ethnic sub-group identities under the umbrella term 'Trio' had already taken place, namely, in the perception of the present-day Trio, those of the Pïrëuyana, Aramayana, Aramiso, Maraso, Okomoyana, and Akïjo. Several of these group identities, however, reappear in the historical sources as operating outside of this Trio hub. Further ethnic groups, as known from written historical sources, that we know were closely related to and interacting with these 'Trio' groups in the mid-nineteenth century were the Pianakoto, Arimikoto, Kirikirikoto, Saluma, and Sikiiiyana. ${ }^{23}$ Nowadays some of these ethnic labels

22 This group started up a foundation in the mid 199os under the name Stichting Xarwoto in an attempt to preserve their language and culture.

23 For example, Kirikirikoto does not appear in the oral traditions of the Trio though written sources do suggest their presence among the Trio (Frikel 1960). In addition, there were people in Alalapadu in the early 196os who claimed Kirikirikoto ancestry. 
have become obsolete, others still have become dormant. This myriad of different parallel identities (linguistic, ethnic and dormant identities) have converged in certain localities where Trio is the dominant language, together forming the Trio hub.

The Trio hub is now located in mid-southern Suriname and northern Pará, Brazil. In the 1840s, the German traveller and boundary commissioner for the British government Robert Schomburgk was the first European to meet 'Drio' in the Upper Corantijn (Schomburgk 1845: 84-85). He considered the 'Drio' to be a sister tribe of the Pianakoto (Pianaghotto), who were much like these but only differed from them by having ornamented their bodies with incisions, "like the South Sea Islanders" (Ibid.). He remarked that the 'Drio' were the only ones he had seen in the Guianas with these kind of bodily ornaments. ${ }^{24}$ From the late nineteenth century onwards, in the written historical sources, the Amerindian people from the above-mentioned area came to be known as the 'Trio' (e.g. Crevaux 1883, Coudreau 1893, de Goeje 1908, Käyser 1912, Schmidt 1942). It was noted, however, that many other peoples e.g., Saluma, Okomoyana, Pïrëuyana, Sikïiyana, etc. were living in the same region as well (de Goeje 1906: 4). As we show below, the name Trio is an adaptation from the name of the original subgroup Tïriyo and thus presently refers to a much larger and more heterogeneous group; in Suriname and in the scientific literature the term Trio is used, in Brazil Tiriyó is used. The autonym of the Trio people themselves is Tarëno, literally, 'the people here', a direct clue to the ethnic make-up of what is now considered to be one ethnic identity. We demonstrate in the following the historical process that brought about this Trio identity.

The first European to describe the Trio as consisting of different sub-groups is the Franciscan priest Protásio Frikel who travelled extensively through the northern part of Pará state, Brazil from the 1940s through the 1960s, a century

24 Later this has understandably been translated as 'tattoos' (de Goeje in FranssenHerderschee 1905: 941), but could not been verified by later sources. Although some of the present day Trio have 'tattoos' on their body today, these should be seen as a recent coastal influence. One wonders if this could be a misperception of Schomburgk since actual 'tattoos' seem rare in this northern part of Indigenous Amazonia. It could be postulated that these incisions were the result of a ritual to restrengthen certain body parts. It has been reported to the second author that in the past incisions were made, for instance, in the hand or the arms of a man to bolster his arching skills. 
after Schomburgk. He distinguished several subgroups that were unified under the collective name of 'Trio', namely, Aramayana 'Bee People', Pïrëuyana 'Arrow People', Okomoyana 'Wasp People', Arimikoto 'Spider monkey People', Kirikirikoto 'Parrot People' and Maraso, a sub-group of the Pianakoto or 'Harpy Eagle People.'. ${ }^{25}$ Moreover, he also added a group of 'wild' Trio groups to which he ascribed Akuriyo 'Agouti People', Wamá, Tiriyómetésem and Wayarikuré (Frikel 1960: 2). ${ }^{26}$

The most thorough study of these groups in the historical sources was carried out by Peter Rivière (1963: 166-176; see also 1969a: 16-26). From his findings we learn that the two groups that were mentioned in the earliest sources are the Aramiso and the Aramayana. The Aramiso ('Aramisas') were reported to be living on the source of the Marowijne river in the late seventeenth century (Harris 1928; Grillet and Bechamel 1698: 30-31, 53). In the eighteenth century they were on the Marowijne and as far away as the Camopi, a tributary of the Oyapock River. In this period we also have the first reports of the Aramayana ('Armagotu') who were living at the headwaters of the Oyapock River (see Rivière 1963: 172-173). Claude Tony ([1769] 1835 and 1843) was the last of the French sources to mention the presence of both Aramiso and Aramayana villages in French Guiana, although some Aramiso individuals were still encountered in the nineteenth century (Rivière 1963: 173). Rivière postulates that at the end of the eighteenth century both the Aramiso and the Aramayana had started to move their villages southwestwards into the Tumuc-Humac region, the former due to Maroons moving into their territory on the Marowijne River and the latter due to Wayãpí intrusions from the south (Rivière 1963: 172-173).

The Pianakoto are first known from reports in the second half of the eighteenth century but a first actual encounter was made several decades later by

25 The question remains what these animal group labels actually reference. Frikel thought that they could be both a xenonym in the form of a collective nickname, but also an autonym. Frikel gives an example for both. In reference to the name Pianakoto (Harpy Eagle People) he states that the Trio explained the ascribed name for this people as that they often have noses like eagles, and that their stare is as strongly focused as that of an eagle. On the other hand, he also states that this sub-group name could also have a deeper meaning for the people themselves. In general, he states, the Trio believe that their souls will live on after their deaths and that they will become what they once were. Frikel recalled a shaman (pïjai) saying to the soul of someone who had just died: "Pijana! Pijana-me tëkë!", which he translated as "Go and become an Eagle again!” (Frikel 1964: 97). A closer meaning is: "Eagle! Go, in the form of an eagle!" Frikel's Trio spelling has been adapted here.

26 We now know that Wama was used to designate the Akuriyo, and that Tiriyometesem simply means 'people like the Trio'. 
Robert Schomburgk in the upper-Corantijn River. ${ }^{27}$ From then on Pianakoto were reported as living at the headwaters of the Trombetas (Pará) but they were also encountered on tributaries of the West-Paru River in the east (Coudreau 1887: 35; Coudreau 1900:79; Guppy 1958: 37). In the mid-twentieth century Frikel encountered Pianakoto living in the same regions. However, some Pianakoto were also present in Suriname since Schmidt encountered two Pianakoto brothers who were both leaders of Trio villages, one on the Sipaliwini River, the other on the headwaters of the Palumeu River. They stated that they had grown up at the headwaters of the Palumeu River. Schmidt also heard reports of a Pianakoto village on the Kuruni River, but in the 1940s apparently only these two Pianakoto brothers had remained (Schmidt 1942: 39). According to the historical sources the Okomoyana were likewise located both in an eastern as well as a western region, but predominantly on the Surinamese side of the north-south water divide. In the late nineteenth century, Coudreau describes the Okomoyana ('Comayana') as living on a tributary of the Marowijne River (Coudreau 1893: 79). This eastern Okomoyana group through time became affiliated with other, in Frikel's words, 'wild' Trio groups (Akuriyo, Wama, Wayarekuré, Tiriyometesem) that were reported to be living in the same region of southeast Suriname. In the early twentieth century Farabee (1924: 214) also reports on a western Okomoyana group located on the Kutari River. In their own oral traditions the present-day Okomoyana show a long history on the Corantijn River and its tributaries (see Mans 2012; see also below).

The movements of the Akuriyo are poorly known. Historically this name has been used by coastal Amerindian groups, such as the Kari'na and Lokono, and hence also by the earliest European colonists, to refer to all the Amerindian groups of the deep interior. This changed when the actual Akuriyo were encountered in the late 1930s, and erroneously called Wama, and 're-discovered' in the late 196os (Carlin and Boven 2002: 32). According to Jara (1991: 21) the Akuriyo are made up of two subgroups, the Turaekare and the Akuriekare. A further group encountered in this area in the 1930s was also the Wayarikure who spoke a Trio-like language but may have actually been the eastern Okomoyana group or at least part of that (Rivière 1963: 174). Since they were contacted and resettled by missionaries in the late 1960s the Akuriyo have been more or less sedentary in the Trio villages. The Trio oral traditions, however, narrate a long history of sometimes violent interaction between the Trio groups and the Akuriyo, as well as an alliance between the Akuriyo and the Okomoyana.

Now we can move to the least known constituent groups of the Trio hub as known from the written sources, namely the Tïrïjo and the Pïrëuyana.

27 See e.g., Schumann (c.1755) cited in de Goeje (1943); Stedman (1796); Rivière (1969a: 18). 
Ma senpo Tarënomene teese, Samuwakapo Tarënomene, nërë Pïrëujana eka. Mono eka serë Pïrëujana, tapïme teese Pïrëujana. Tïrïjoton, irëpo Tïrïjo nkan, irëpo Akïjo, Akïjonkërë. Tarëno apo nërë Akïjo. Koelewijn (1984: 230, spelling adapted by Carlin)

Well, here at Samuwaka there were the Tarëno groups, the Tarëno groups, their name was Pïrëujana. This is an inclusive name, P̈̈rëujana, there were many Pïrëujana groups, Tïrïjo for example, there they called them Tïrïo and Akïjo and other Akïjo peoples. Those ones, the Akiijo are like the Tarëno. Translation Carlin (2004: 14)

The oral histories suggest that the Tïrïo were first of all a subgroup of the Pïrëuyana hub which would later become the Trio hub. Both identities are poorly reported in written documents probably due to the relative inaccessibility of their locations at the time, compared to most of the other abovementioned groups. A first note on the Pirëuyana in the historical sources is by de Goeje who heard, probably from the Wayana, that they spoke a language like Wayana and lived in very large houses on the (until now unidentified) Pletani River (de Goeje 1906: 4). A first note on the 'Tïrïjo' in historical sources, can be found in a letter from a post holder (Meyer) to the Governor dated to 1796 (Carlin 2004: 14). The name of this subgroup seems to be unrelated to the later collective 'Trio' identity subsumed under the autonym Tarëno which literally means 'the people here'.

This onomastic practice stresses the importance of converging movements and localities in the construction of umbrella identities. As stated above, as to the origin of the name 'Trio' as we use it, it clearly derives from this former subgroup identity the Tïrïo. This term was appropriated by non-Amerindian outsiders to refer to a collective of people who presently refer to themselves as Tarëno. Thus, we can say that the term 'Trio' is a Western historical construct, originally a native term that has become a xenonym. In turn this xenonym has become appropriated by the present-day Trio communities in their dealings with outsiders as they present themselves to others as Trio. Thus this collective has two autonyms, one for internal use only, Tarëno, and one for presenting themselves outside of the group, Trio. ${ }^{28}$

28 An additional complication is the fact that nowadays the term Tarëno is also used by the Trio as a general noun meaning 'Amerindian person', which seems to be replacing the noun wïtoto '(Amerindian) human being'. Once again, we see in this terminology that most Amerindian groups tend to see themselves as the only real Amerindians. 
Currently the Trio live in five main villages and ten smaller settlements in Suriname and in one main village (Tiriyó Missão) and several smaller settlements in Brazil, see Fig. 4.1. Our focus is now on the Surinamese settlements: in the east they live in Palumeu, and Kassikassima on the Palumeu River and in Tëpu on the Upper Tapanahoni. Most Trio live in the west, in Sipaliwini village on the river of the same name, and in Kwamalasamutu and Alalapadu on the Upper Kuruni River. ${ }^{29}$ Close to Kwamalasamutu there are three small settlements on the Kamani and Kutari rivers. Further northwest there is one more village along the Kuruni River, and further west along the Corantijn they live in the villages Casuela, Amotopo, and Lucie. Even further downstream along the Corantijn, there are villages just below the Wonotobo Falls, and one close to Apoera, in Trio called Wanapan or Arapahtë and Sandlanding respectively (see Carlin and van Goethem 2009; Mans 2012). The largest and ethnically the most heterogeneous village of Kwamalasamutu, as described in Section 2.1, has witnessed several dynamic developments in the past two decades. Internal political and social tensions, dwindling forest resources per capita, and regional political strategies have all led to the changing face of the Trio community of Kwamalasamutu. Since this period we can observe movement away from this village to the west by different families and a re-awakening of dormant identities. In the following we focus on the history of the Okomoyana family of Amotopo, showing their movements in and out of Kwamalasamutu and the relation of these movements to identity-changing processes.

\subsection{Awakened Dormant Sub-identities}

Let us start with Anapi. Anapi was leader of the eponymous village close to the Tukuimïn mountain and the great-great-grandfather of Paneshi Panekke, the present day captain of Amotopo. Not much is known about this village except that the existence of Anapi and his village were mentioned to the early Dutch explorers in the region (de Goeje 1906: 3; Käyser 1912: 46; see also Rivière 1969a: 318, no. 296). Another village nearby, Langoé, which was visited by de Goeje in 1907 as a Trio village, was allegedly a Rãgú village, Rãgú being a subgroup of the Pirëuyana, (Frikel 1957:555). Ëujari, who was a grandson of Anapi, told Rivière in the early 196os that his father (Sawirapo or Tunawakka) was a Pïrëuyana, as was the mother of his deceased son's wife. The Trio stereotyped the Pïrëuyana as always shooting arrows and having thin legs like arrow cane

29 On different maps, the river flowing through Kwamalasamutu is given now as the Sipaliwini, now as the Kuruni. 
(Rivière 1969a: 22). ${ }^{30}$ It is unclear what identity Ëujari ascribed to himself, but Rivière stated that from his slender looks one could easily guess his identity.

Ëujari himself became the village leader of Panapipa on the Upper Kuruni River (Wiumi). This village was known as a large and good village, with a strong leader, (Rivière 1969a: 213, 233; Healy et al. 2003: 39) that attracted many people from the Sipaliwini basin, approximately two thirds of the later inhabitants of early Alalapadu as documented by Rivière in the early 1960s (see Mans 2012: 136-145). In the early 196os, Ëujari met with the American missionary Claude Leavitt and his small Waiwai group. Probably through Ëujari's mediation, his successor, Pesaihpë, decided to move with all the inhabitants of Panapipa to the missionary's village, Alalapadu, which was situated near a Brazil nut grove on the Araraparu creek. ${ }^{31}$ In Panapipa, Ëujari's son had passed away, but together with his wife, an Okomoyana, and his grandsons, Paneshi and Pikuku, Ëujari moved to Alalapadu where they met up with Peter Rivière.

Rivière's observations were that all the inhabitants of the village had but one Trio identity. He asked the villagers about the sub-identities, the existence of which they confirmed, but which they considered to be something of the past. He states:

there is ample if not firm evidence to suggest that the Tumuchumac region has been an area of intertribal mixing, and the vital question is how important are these sub-groups or tribal remnants in the present composition of the Trio and whether there is any advantage to be gained in distinguishing them. It is possible to say with assurance that whatever the distinction may have been previously it is now virtually non-existent. The Trio, even if they are composed of previously independent groups who reached the area from different directions at different times, now think of themselves, with the possible exception of the Aramayana on the West-Paru, as a single group, having a common name, language and culture. (Rivière 1969a: 27-28)

30 Another report to Frikel refers to bundles of arrow reed the Pïrëuyana often carried around (Frikel 1957: 555; Rivière 1969a: 22).

31 The spelling of the village and the creek differ here because the village Alalapadu is known as and found on all maps with this spelling, but the original Trio spelling is that as given in the name of the creek. 
After Rivière's fieldwork, more Trio arrived in Alalapadu predominantly from the Brazilian side of the Tumuc-Humac. When Ëujari's grandson Paneshi grew up he married a Brazilian Trio. With the high number of Brazilian Trio arriving in Alalapadu, together with a positive birth rate, the village soon grew to approximately 500 inhabitants. After some time, its position along the small Araraparu creek appeared unsustainable for this large number of people. Together with the missionaries the people from Alalapadu moved to another locality where they founded Kwamalasamutu. The Waiwai had already been present in Alalapadu, but in Kwamalasamutu they grew to a group of approximately 200-300 Waiwai speakers, as we saw in Section 3, belonging to different ethnic groups.

Contrary to what Rivière encountered, researchers in the 199os found that the people of the until then allegedly monolithic 'Trio' identity had 'awakened' their dormant sub-identities (see Fig. 4.1). Paneshi Panekke appeared to be Okomoyana, a sub-identity which Rivière was told in Alalapadu was extinct (Rivière 1969a: 20-21). Paneshi's ascription to the Okomoyana sub-identity can be hypothesised along two lines. In the first instance his grandmother Tawirujë, the wife of his grandfather Ëujari, apparently was an Okomoyana. A second Okomoyana line follows his stepfather. His mother, Aijatu (whose mother in turn was a Pïrëuyana), was remarried to Sipi. He, in turn, was an Okomoyana since his mother (Paruparu), and possibly also his father (Imaina or Eemainan), allegedly came from Pehkëtë, the region of the Okomoyana ancestors below the confluence of the Kuruni and the New River, see Fig. 4.1 (cf. Mans 2012). ${ }^{32}$ Paneshi's wife, Apëhpïn, appeared to have the Sakëta subidentity. This Brazilian Trio sub-identity, Sakëta, is not mentioned anywhere in the historical sources nor in the Trio oral traditions. Together with the Aramayana they appear to have moved to Alalapadu shortly after Rivière's fieldwork. At that time, the Surinamese Trio did not appear to know much about the Aramayana any more (see Rivière 1969a: 22-25). ${ }^{33}$ In Alalapadu, Paneshi's grandfather Ëujari passed away.

32 It is not entirely clear whether Pehkëtë is one spot, possibly a former village, or whether the name refers to the area just north of Tigri up as far as the confluence of the Lucie and the Corantijn.

33 The Aramayana are mentioned several times in the oral traditions, for example, in the story of the big flood, their leaders, and also those of the Maraso, are said to have followed the Pïrëuyana to Kantani mountain to escape to higher ground (see Koelewijn with Rivière 1987: 150). 
The above-mentioned awakened sub-identities became further enforced when in the 199os, at the request of the Paramount Chief Asongo Alalapadu, the Okomoyana captains and stepbrothers Paneshi Panekke and Pepu Ipajari (son of Sipi) moved with their families from Kwamalasamutu to found new villages along the Corantijn, see map in Fig. 4.1. The Paramount Chief himself claims to have the Pïropï sub-identity. Literally, the Trio word piropï means 'chest'. Pïropï as an ethnic ascription is a descriptive term that is said to refer to the core-group of the Trio, the real Trio. In Frikel's survey in the midtwentieth century, the sub-identity 'Prôupe' is mentioned (Frikel 1957: 555), which he states is another name for the Pirëuyana. That the Pïrëuyana represent the core of the Trio collective makes sense in the light of the aforementioned oral histories of the Trio.

The Okomoyana families moved to Pehkëtë where the Okomoyana ancestors are said to be buried. However, they were not the only ones to leave. From the mid-199os different Trio families started to leave Kwamalasamutu, once again, at the request of the Paramount Chief. In the Western Trio Group, which came into existence as a result of the fissioning of Kwamalasamutu, one can now observe, for instance, that the new villages are being referred to, amongst themselves, as a Sakëta village (Kuruni), an Okomoyana village (Amotopo), an Aramayana village (Wanapan-Wonotobo Falls) and a Mawayana village (Casuela), a process that reinforces the distinct identities of the different localities. ${ }^{34}$

This is not to say that the inhabitants of any single one of these villages all have the same sub-identity, but it seems to reflect the sub-identity of the village leader or that of his family. It is, however, unclear how such a sub-identity is exactly inherited. Although its ascription seems fluid and arbitrary, it does refer back to the sub-identity of one of the ancestors. Some people are perceived to have a mixed identity, whereas others claim to have a single subidentity while in essence they too are of mixed descent.

As the Trio hub case study has shown, the sub-identities had become dormant from Alalapadu up to Kwamalasamutu where they re-emerged. This is comparable to the Waiwai case presented earlier where the sub-identities apparently fused in Brazil and Guyana and re-emerged among the Waiwai speakers in Kwamalasamutu. In turn, in the fissioning off from Kwamalasamutu, new and dispersed localities were being inhabited and in the process these re-emerged sub-identities became reinforced and ever stronger.

34 In principle, these labels are not used outside of the Trio hub. We could postulate that the reinforced identities contribute to a higher sense of village autonomy. 
As the two case studies have shown, the notion 'Amerindian identity' is neither a uniform nor a single category, rather an individual can ascribe to several identities and can uphold these as in a Matryoshka, or nested Russian dolls, fashion, that is, each individual is his/her own matryoshka doll.

As stated above, identity is an interaction with the social landscape. It is an ontological stance that is intricately bound to the greater physical landscape, the locality, and as we have shown, it is highly relational. Furthermore, it also involves ecological, cosmological, and historical knowledge systems. ${ }^{35}$ No one individual exists in a vacuum, rather ethnic identity is a negotiation that results in different outcomes depending on the self-positioning of the negotiators.

Approaches to identity in mainstream social and cultural anthropology are generally primordialist (objective biological or cultural ethnic identities), instrumentalist (political), or constructivist (socially organised mechanisms of identity), though these are not necessarily mutually exclusive categories (see Hornborg and Hill 2011: 2). However, in all three approaches lurks the danger of essentialising cohabiting groups whereas the social ontology of all perceived discrete ethnic units in the Guianas is, in a historical sense, complex and thus neither monolithic nor fixed. For example, as we have shown, what we perceive as 'the Trio' group in Kwamalasamutu, is much greater than the sum of its parts. Structurally, and politically, the result of the so-called fusions is not per se an absorption of cultures into one dominant culture, as has been claimed until now, rather the result is a multiplicity of non-hierarchical structures, within which there is a horizontal meshing together of groups. The political leadership towards the outside is then decided by consensus and/or local governments' ideas of representation. It is precisely this multiplicity that allows the nested identities to co-exist.

For outsiders, the ethnic granularity of the Amerindian peoples in the Guianas is not immediately apparent, in part because of what Rivière (1969b; 1984) calls a core cultural invariant around which there is a great deal of variation. ${ }^{36}$ Outside of this core invariant ethnic differentiation is found, for

35 In this chapter we restricted ourselves to the relationality of the social and physical landscapes rather than other dimensions such as the ecological and cosmological meaning and significance of these landscapes. This omission should not be interpreted as relegating less importance to these aspects.

36 Examples of the core invariant are such aspects of the social organisation as "lack of emphasis on descent, the importance of residence in ordering social relationships, bilateral crosscousin marriage, and a tendency towards matrilocal marriage" (Rivière 1969b: $162)$. 
example, in material culture, bodily adornment, and myths. Another reason is that umbrella ethnonyms obscure the ethnic constitution and linguistic practices of a given group. On the one hand, language and modes of communication may be good indicators of ethnic allegiance. However, since languages can be abandoned, adopted or radically changed through contact, they are not always the most reliable indicator. Moreover, shared [biological] history and location [habitat] are also paramount to establishing ethnic identity. In Barth's terms, shared language and history constitute boundaries of cultural identity (Barth 1998); we have shown here that these boundaries are fluid and that movement results at any time in a kaleidoscopic contortion (cf. Rivière 1984). Among the Guianan, or perhaps Amazonian Amerindians more generally, the primordial or biological identity tends to be buried deep under several layers of superimposed yet non-vertically perceived other identities. In particular, identity is multi-facetted and consists of spatial and temporal contingencies that comprise a people's history.

In sum, both dormancy and emphasis of sub(group)-identities are the result of movements of people. Moving several subgroups into a large village together in which one language is or becomes dominant (that of its village leader), over time causes sub-group identities to become dormant towards the outside only. As we have shown in the case of Kwamalasamutu, when people move out of this village with their families, found a new village and become village leaders themselves, these dormant ethnic sub-identities re-emerge as the identity that is projected to the outside world, albeit without a separate linguistic distinction. In such cases, the link between language and identity is tenuous at best, and incongruous at worst. Proclaimed identities and ascribed identities (autonyms and xenonyms) are both the result of movements of people. A macroidentity comes into being when several groups are united by a shared locality and subsequently become conceptualised as, and present themselves as, a unit by another group.

As to why some of these particular identities fell dormant, three hypotheses can be put forth. First, given that both the Waiwai and the Trio ethnogenesis coincides with missionary activity in the relevant areas, it could be argued that missionary work played a major role in the homogenisation of these two groups, albeit in name only. It is not inconceivable that the first missionaries needed unity and peace among the inhabitants of the missionary villages, and of course a common language into which the Bible could be translated. Psychologically, therefore, the unity of the Waiwai and the Trio had to be stressed, thereby downplaying diversity or making it undesirable, not to say downright anti-social to live out any nested identity one might have. The 
second hypothesis dismisses the first by claiming that this dormancy effect, as part of the cultural kaleidoscope, is subject of a deeper history beyond the reach of the missionaries. Nesting identities was possibly an indigenous strategy to help people fuse in times of necessity, such as when there was a threat of decimation through sickness, wars, etc. Moreover, the Amerindian world is a highly relational one in which co-residence generally trumps consanguinity, and in the social landscape, memory and forgetting form an essential strategy for easing Amerindian interactions. ${ }^{37}$ There is also an argument for our third hypothesis, however, namely that an overarching 'Waiwai' or 'Trio' identity never actually existed and that these should be seen entirely as recent historical constructs. Waiwai, presumably a xenonym, was taken over by westerners for ease of reference to a rather motley group of people with different languages and cultures. The practice was then continued by the people themselves. The name 'Trio', originally based on a misconception and subsequently applied by western explorers and scholars to the people speaking the Trio language, through time became adopted by the 'Trio' themselves as a point of reference in order to ease communication with these outsiders. In other words, both the Waiwai and the Trio consciously perform their Waiwai-ness and Trio-ness to the outside world. ${ }^{38}$ It is also possible, of course, that these three hypotheses are not mutually exclusive but that various factors from each have played a role together.

What we have shown is that locality, and thus also movement, play a major role in determining which contained identity is presented; a claim to one's own locality results in the highest resolution of identity. As noted above, each of the smaller ethnic groups in Kwamalasamutu, the Mawayana, Tunayana-Katwena, Sikiïyana, and Akuriyo have their own 'area' within the village and thus also had the space (locality) to allow their nested identities to re-emerge. Thus of all the groups given above, a Mawayana in Kwamalasamutu will have the most 'Matryoshka dolls' in his/her set, the outer doll being Trio, the next one

37 It is known, for example, that skills for manufacturing certain artifacts can easily be forgotten in order to perpetuate a social system of exchange. When peaceful trade relations turn sour, however, manufacturing skills appear to be easily recovered (Chagnon 1968; Rivière 1969a; Mans 2012). It could be argued that a similar strategy operates on a political level of village organisation.

38 When people from Kwamalasamutu are in Paramaribo, regardless of their ethnic affiliations, they present themselves as Trio, likewise the wares they sell there, such as decorative arts and crafts or other artifacts, are now all considered and labelled Trio. However, the differentiation in artifacts and patterns on basketry etc. does exist in the village Kwamalasamutu although only the homogenised artifacts are brought to the capital. 
Waiwai, the following one Mawayana, and the next one Wadayana, Jiwiyana, or Buuyana. This is thus what it means to be a Mawayana, one is simultaneously Trio, Waiwai, Mawayana, Buuyana (or Jiwiyana or Wadayana). Through movements in the physical landscape and thus also in the social landscape, identities are renegotiated as much from the inside as from the outside. 